\title{
PRICE AND QUALITY OF COFFEE (COFFEA ARABICA L.) DRIED USING AIR DEHUMIDIFIED BY CONVECTION
}

\author{
Evandro A. Konopatzki ${ }^{1 *}$, Divair Christ ${ }^{2}$, Silvia R. M. Coelho ${ }^{2}$, Angélica Demito ${ }^{3}$, Ivan Werncke ${ }^{2}$, \\ Rafaela G. da M. Camicia ${ }^{2}$
}

${ }^{1 *}$ Corresponding author. Federal University of Technology/ Medianeira - PR, Brazil.

E-mail: eakonopatzki@utfpr.edu.br | ORCID ID: https://orcid.org/0000-0002-9950-4561

\section{KEYWORDS}

air dehumidifier, artificial drying, coffee dryers, electric dryer.

\begin{abstract}
Grain drying processes have been improved to reduce costs and losses of coffee beverage quality. The objectives of this study were to evaluate the quality of coffee dried using air partially dehumidified before entering drying units (DUs) in four coffee-producing farms, as well as the effects of such process on coffee commercial value. The method consisted of obtaining three samples (triplicates) of coffee dried in both DUs and concrete terraces (control) for mean multiple comparisons. The following variables were analyzed for sieve \#13 and hand-picked beans: defect number, cupping test, and pricing. Evaluations were carried out by three professional graders. The results showed that coffee dried in the DUs presented fewer broken grains, higher cupping score, and less negative factors of handsorting and defects. As a conclusion, it should be emphasized an average increase of $12.11 \%$ in price for coffee beans previously dehumidified.
\end{abstract}

\section{INTRODUCTION}

Coffee is one of the most consumed beverages worldwide and has great socio-economic relevance in Brazilian agriculture, and is grown mainly by family farms (Batista et al., 2010; Aparecido et al., 2015; Zelber-Sagi et al., 2015 and Aparecido et al., 2016). According to CONAB (2017), coffee production has increased significantly in recent years, even under strong climate influence and variation from one harvest to another, rising from 1.73 million tons in 2003 to 2.70 million tons in 2017 , with a planted area of $2.21 \times 10^{6}$ ha and an average yield of 24.10 bags ha ${ }^{-1}$.

To adjust seasonal production to continuous market demand, efficient grain processing and storage are required. Drying in concrete terraces is the most widespread method for coffee, but if not properly managed, can cause fermentation, breaks, cracks, fungal growth, or smoke odors, which lower coffee quality and reduce its commercialization price (Coradi et al., 2008; Palacin et al., 2009; Abrahão et al., 2010 and Martinez et al., 2013).

With the advances in drying air dehumidification (e.g., heat pipe technology - HPT), electricity became part of the drying process in a financially competitive scenario. In Brazil, HPT was firstly applied in peanut drying by Krzyzanowski et al., (2006a), as well as in soybean by
Krzyzanowski et al., (2006b); Levien et al., (2008); and Avelar et al., (2011). These authors used dehumidified air to dry seeds and found a reduction in drying time and greater maintenance of seed physiological quality.

No reports have been found in the literature on the use of such dehumidifying technology for coffee drying apparatus. Coffee grains are dried in units containing an air treatment unit (ATU) connected to tray dryers with Wshaped false bottoms. By reducing the humidity ratio of the drying air, the capacity of removing water from the coffee mass is increased, which occurs by increasing water vapor difference and reducing drying time in order to attain an ideal moisture content for storage. However, during this process, it is essential to maintain the quality of coffee beans to meet consumers' demands.

The quality of Brazilian coffee is defined by rules for analysis and evaluation of coffee beans, which are based on the counting of grain defects, grain uniformity, impurities, and sensory analysis (Brasil, 2003). Santos \& Nantes (2014) classified coffee lots using a seven-score scale, starting with type two (up to four defects) and ending with type eight (360 defects or more). The coffee beverage is then classified according to the aroma, body, and flavor as hard (70 to 74), softish (75 and 79), soft (80 to 84 ), and strictly soft (84 to 100 points).

Considering the use of air-dehydration equipment in commercial-scale coffee roasting, this study aimed to

${ }^{2}$ Western Paraná State University/ CCET/ PGEAGRI / Cascavel - PR, Brazil.

${ }^{3}$ Federal University of Pelotas/ Pelotas - RS, Brazil.

Received in: 7-2-2018

Accepted in: 7-20-2019 
evaluate the quality of coffee grains dried in air treatment units (ATU) coupled to dryers $\left(\mathrm{SBJ}^{\circledR}\right)$ to test the hypothesis that coffee quality is not reduced in comparison with coffee dried in concrete terraces.

\section{MATERIAL AND METHODS}

The study was carried out from May 2016 to October 2017, in four farms located at the following SAD69 coordinates: (-22.21, -49.66), (-21.79; -48.18), $(-20.54,-47.42)$, and $(-20.78,-47.10)$. At the request of the owners, the farm units were randomly named as DU-A DU-B, DU-C, and DU-D, to ensure that the involved farms would not be identified.

Each farm has an air treatment unit (model UTA$\left.120^{\circledR}\right)$, manufactured by Cool Seed Ltda. It has the following characteristics: $148 \mathrm{~kW}$ electric power, $363,636 \mathrm{kcal} \mathrm{h}^{-1}$ refrigerating capacity, and $75 \mathrm{~m}^{3}$ volumetric capacity per batch. The unit is composed of 5 vats of $15 \mathrm{~m}^{3}\left(\mathrm{SBJ}-15^{\circledR}\right)$, with a W-shaped false bottom (FIGURE 1).

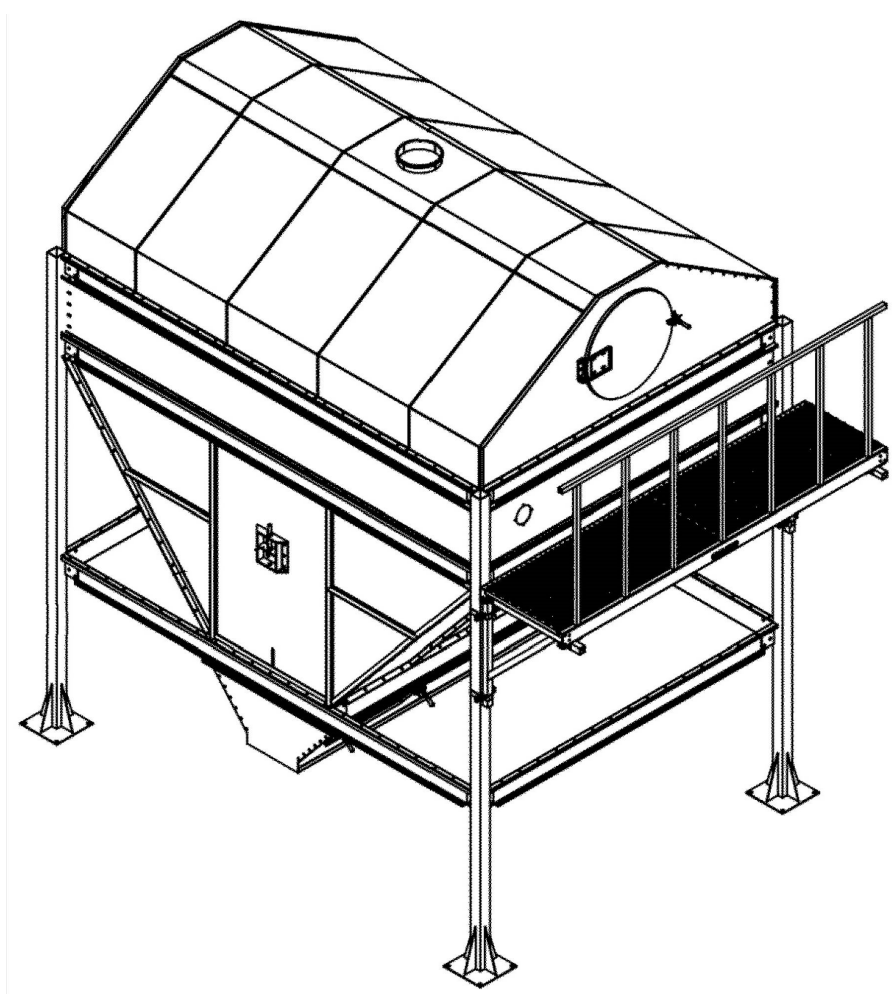

(a)

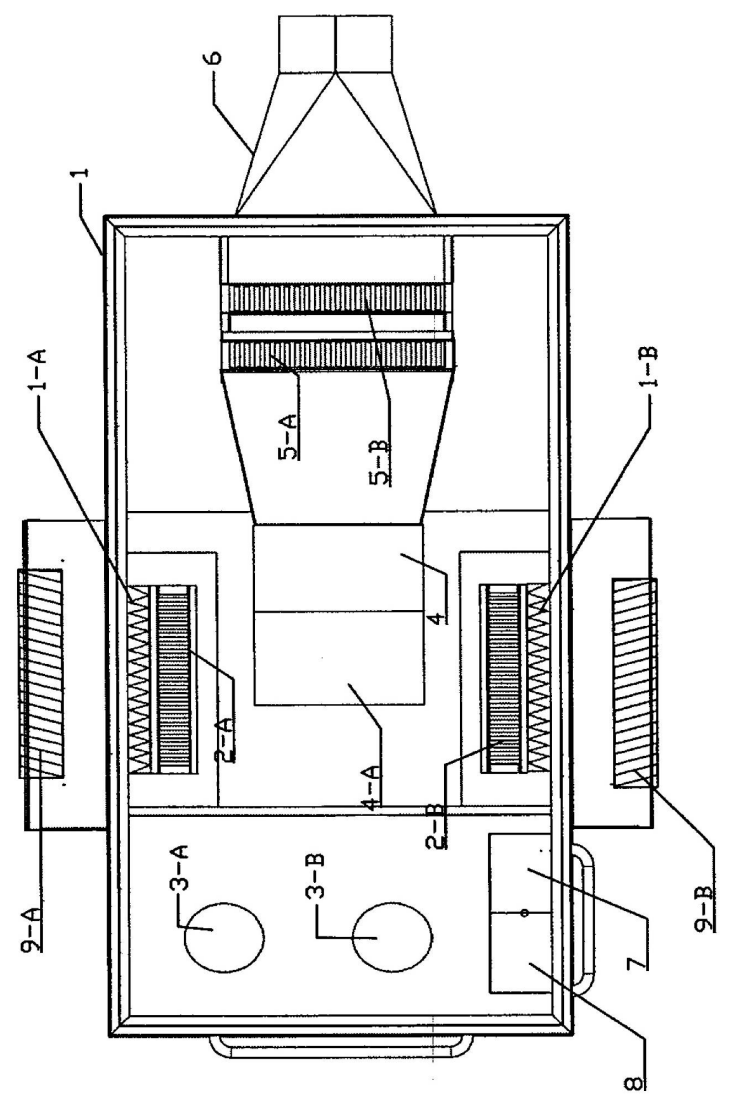

(b)

FIGURE 1. Front view of a tray dryer module - $\operatorname{SBJ}^{\circledR}$ (1a), and Top view of the air dehydration equipment - ATU (1b)

Source: SBJ ${ }^{\circledR}$ front view was adapted from Barreto (2013) and the ATU top view was adapted from Barreto (2012).

Notes: 1: AWU metal structure body; 1-A and 1-B: pleated air filters with great capacity for air dust, and dirt retentions; 2-A and 2-B: evaporator coils; 3-A and 3-B: compressors; 4: fan; 4-A: fan engine; 5-A and 5-B: condenser serpentines; 6: dry air outflows; 7: control panel; 8: power table; 9-A and 9-B: dumpers (two) outdoor-air intake.

The cooling capacity of these units was designed to maintain drying air between 45 and $50{ }^{\circ} \mathrm{C}$, and relative humidity between $10 \%$ and $20 \%$.

\section{Drying routine in concrete yards}

Sampling consisted of mechanically harvested grains without being subjected to washing and separation processes. Coffee grains sampled from concrete terrace or DU lots were not previously selected. A grain volume of $75 \mathrm{~m}^{3}$ was deposited into the dumper and later transported to the dryers $\left(\mathrm{SBJ}^{\circledR}\right)$, while the harvest surplus was taken to the yard, as shown in FIGURE 2. 


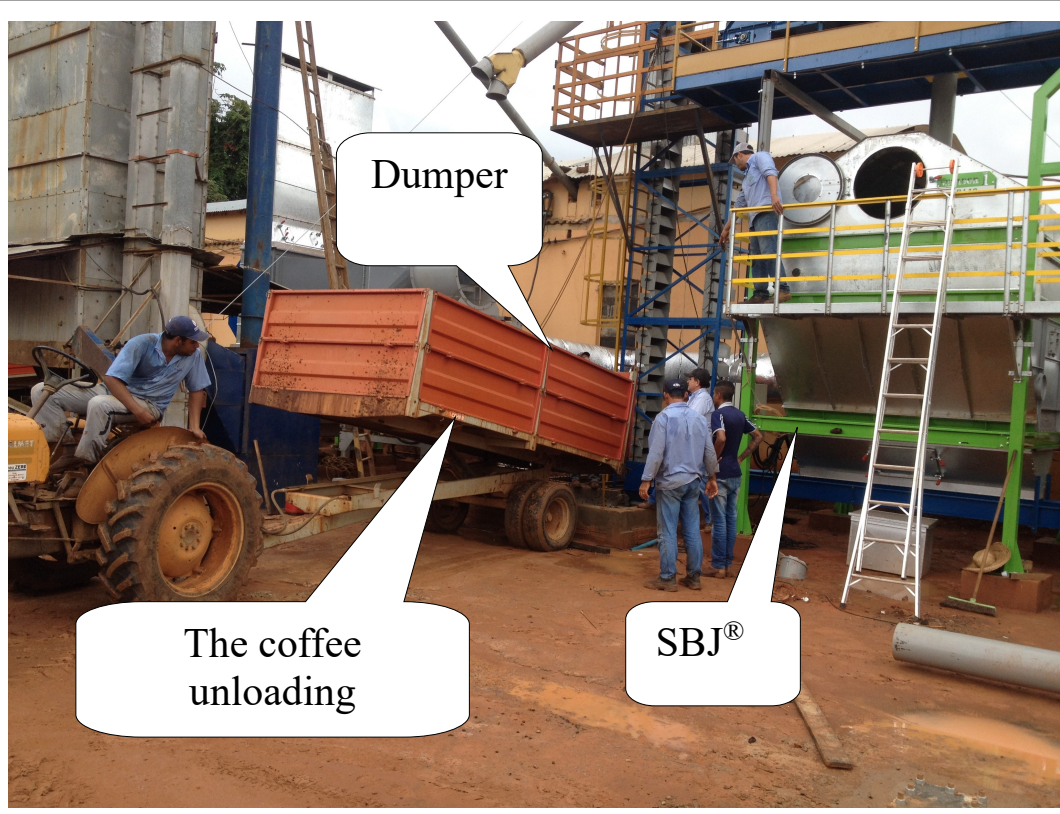

(a)

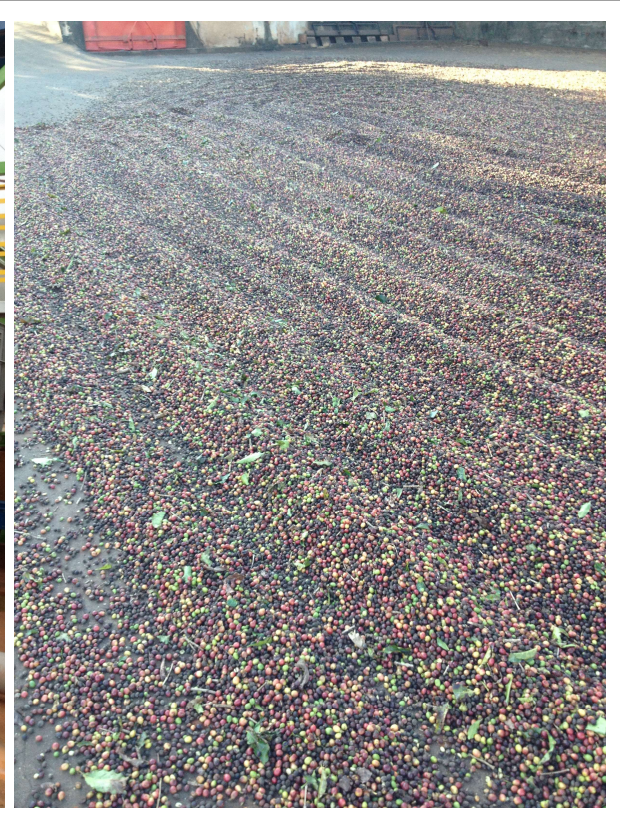

(b)

FIGURE 2. Images of the coffee unloading in a DU (2a) and coffee beans spread out to dry on a concrete terrace (2b)

Coffee control samples (concrete yard) were daily spread in 0.05-m layers. During the first days, coffee was constantly stirred using a broomstick attached to a motorcycle and by manual sweeping.

With the help of a tractor and leveling shovel, coffee beans were piled up and covered with canvas every night. The heaps were $2.0 \mathrm{~m}$ high. At the beginning or end of the rainy seasons, heaps were uncovered, and grains were spread all over the paved terrace.

After the fifth drying day, grains were spread in layers and heaped in piles spaced about $0.5 \mathrm{~m}$ about or farther (FIGURE. 3).

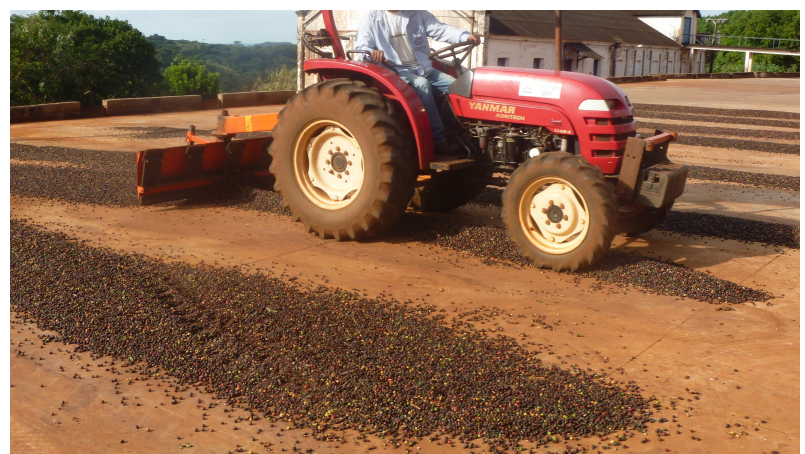

(a)

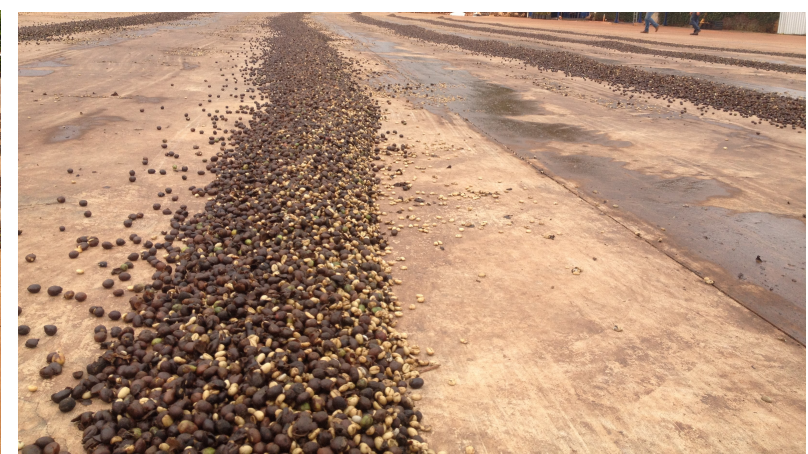

(b)

FIGURE. 3 Images of the coffee spreading all over the concrete terrace (3a) and coffee heaping (3b)

\section{Drying routine in DU`s}

FIGURE 4 shows the drying airflow in DU's. The air enters ATU at room temperature and relative humidity, and it exits the driers saturated with moisture. After entering the dryer, coffee beans are periodically transferred to the next unit for stirring.

Drying routine in units consisted of injecting dehydrated air into the driers $\left(\mathrm{SBJ}^{\circledR}\right)$ for about 20 hours, carrying the grain mass from one to another, followed by a resting period. This way, moisture could be homogenized, simulating the turning of coffee heaps on the terraces. 


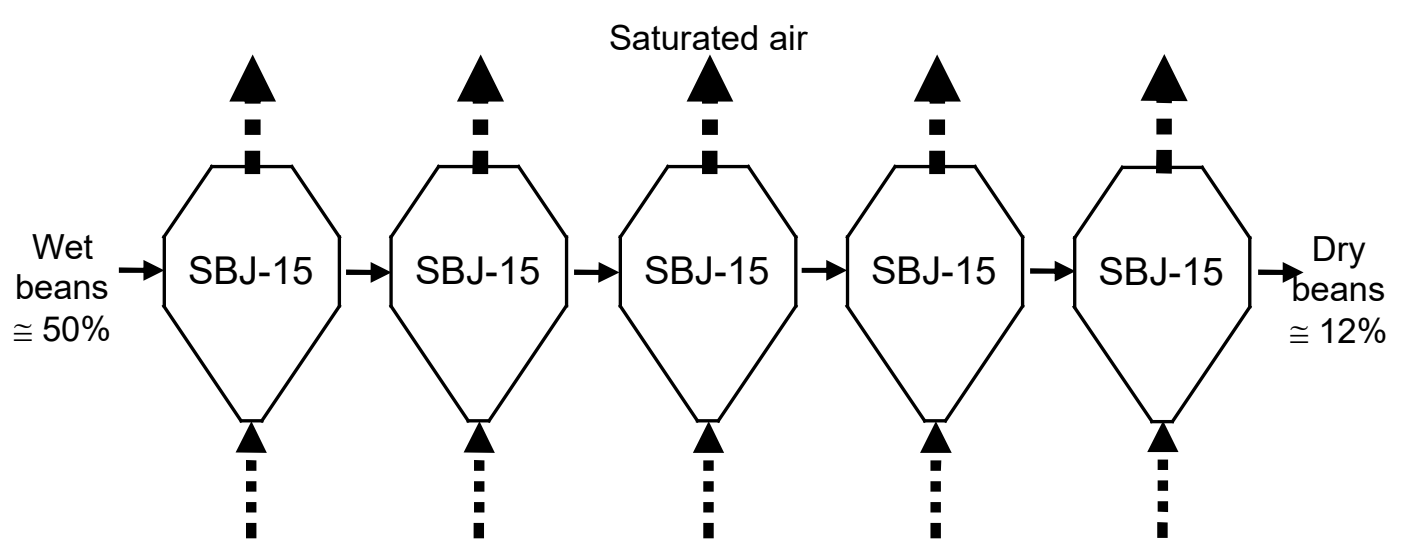

Air at high temperature: between 45 and $50{ }^{\circ} \mathrm{C}$, and reduced

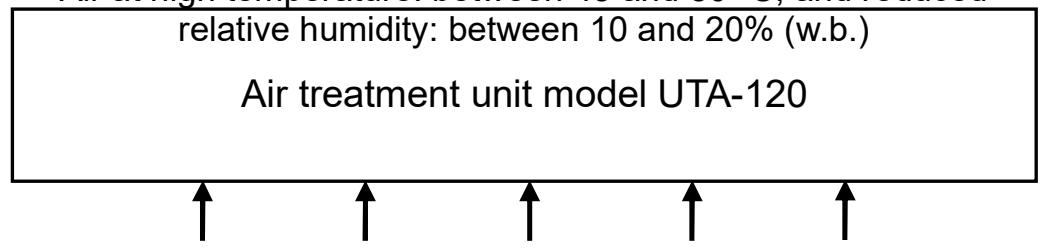

Room temperature and relative humidity

FIGURE 4. Flow diagram of coffee drying by air heating and dehumidifying

\section{Coffee samples}

Table 1 shows the assessed coffee varieties, initial grain moisture, and drying-air temperature and relative humidity when the grain mass entered and left the system.

TABLE 1. Composition of coffee variety, moisture content, and drying-air properties in the agricultural units (farms).

\begin{tabular}{|c|c|c|c|c|c|c|}
\hline Agricultural Units & Variety & $\begin{array}{c}\text { RHGI } \\
(\% \text { w.b.) }\end{array}$ & $\begin{array}{c}\text { RH }_{\mathrm{ARSE}} \mathrm{O} \\
(\%)\end{array}$ & $\begin{array}{c}\text { T }_{\text {ARSE }} \\
\left({ }^{\circ} \mathrm{C}\right)\end{array}$ & $\begin{array}{c}\mathrm{RH}_{\mathrm{ARSA}} \mathrm{S} \\
(\%)\end{array}$ & $\begin{array}{c}\text { TARSA }_{\text {ARS }} \\
\left({ }^{\circ} \mathrm{C}\right)\end{array}$ \\
\hline Farm-A & Topázio & $55 \pm 5$ & $13 \pm 5$ & $45 \pm 2$ & $70 \pm 8$ & $25 \pm 3$ \\
\hline Farm-B & $\mathrm{MN}+\mathrm{C}^{(1)}$ & $45 \pm 4$ & $13 \pm 5$ & $45 \pm 1$ & $72 \pm 5$ & $26 \pm 2$ \\
\hline Farm-C & Mundo Novo & $50 \pm 6$ & $15 \pm 5$ & $45 \pm 2$ & $70 \pm 5$ & $24 \pm 4$ \\
\hline Farm-D & Mundo Novo & $60 \pm 5$ & $15 \pm 4$ & $45 \pm 2$ & $75 \pm 4$ & $24 \pm 3$ \\
\hline
\end{tabular}

Notes: RHGI: initial moisture of grains measured immediately before drying; w.b.: wet basis; RHARSE: drying-air moisture measured at the ATU outlet; $\mathrm{T}_{\mathrm{AR}} \mathrm{SE}$ : drying-air temperature measured at the ATU outlet; $\mathrm{RH}_{\mathrm{AR}} \mathrm{SA}$ : output air relative humidity measured at the outlet pipe of the $\mathrm{SBJ}^{\mathbb{R}}$ dryer; $\mathrm{T}_{\mathrm{AR}} \mathrm{SA}$ : output air temperature measured at the outlet pipe of the $\mathrm{SBJ}^{\mathbb{R}}$ dryer.

(1) Grain samples composed of $80 \%$ Novo Mundo and 20\% Catuaí.

\section{Coffee sampling and quality characterization}

Grain moisture content was monitored during the drying using an Agrologic moister meter (AL-102 ECO; serial number 102634), which was calibrated using an oven method at $105^{\circ} \mathrm{C}$ (Brasil, 2003).

After sampling, coffee cherries were pulped and sieved at the respective farm. Then, they were packed, labeled, and stored in Styrofoam boxes (CATP). These samples were used for coffee quality analysis. Sensory analysis (or 'cup test') was conducted by trained testers, following the standards of the Brazilian Ministry of Agriculture, Livestock, and Food Supply (Brasil, 2003).

Three random sub-samples $(0.33 \mathrm{~kg})$ were removed from each sample and sent to the testers. They set up triplicates of $0.1 \mathrm{~kg}$ for each sub-sample, which were homogenized and sieved through a \#13 sieve over a black paperboard (Brasil, 2003). The grains that passed through sieve \#13 were denominated as bottom and counted together with the hand-picked material.

Next, the presence of sticks, stones, husks, and dirt —which are considered as impurities - were analyzed. Black, green, and sour beans, also called hand-picked, were separated as well.

Subsequently, the cup tests were performed in 10 cupping sessions, and scores were measured as the average of evaluations. Scoring was based on the method described by the Specialty Coffee Association of America (SCAA), as proposed by Lingle (2011).

After beverage tasting results, the tasters priced the samples at a $60 \mathrm{~kg}$ coffee bag base, using quotation of September 12, 2017. assessment.

FIGURE 5 displays coffee sampling and quality 


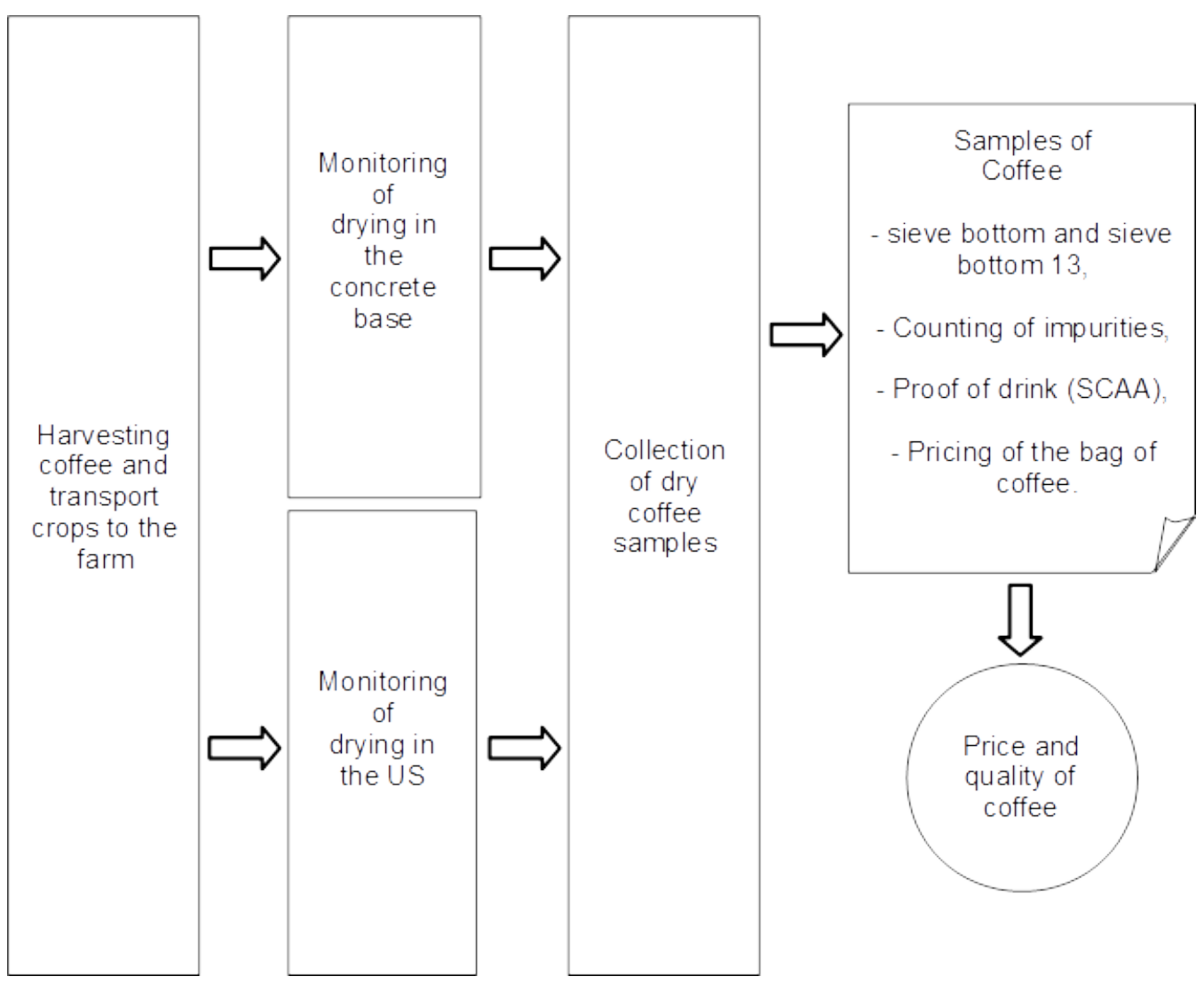

FIGURE 5. Flowchart of the coffee sampling and quality analysis.

Data on hand-sorting, defect number, scoring, and pricing were organized by farm and analyzed by one-way analysis of variance (ANOVA), using means of samples of coffee dried on terraces and Dunnett's test at 5\% level of significance. This analysis was carried out under the null hypothesis that the quality of coffee dried with dehydrated air is not different from that of coffee dried on concrete terrace.

The means of each factor (hand-sorting, number of defective beans, scoring, and pricing) were compared by the Tukey's test at 5\% significance level to evaluate the variability in drying process among the DU's. Data normality was analyzed by the Shapiro-Wilk's test (W) for residual distribution at 5\% significance.

\section{RESULTS AND DISCUSSION}

\section{Average drying times of coffee lots on terraces and in DUs}

The mean drying time of coffee grains in the DUs was $83.33 \pm 6.90 \mathrm{~h}$, corresponding to a water withdrawal rate of $0.48 \%$ (w.b.) per hour, while the mean time in the control (concrete terrace) was $196.02 \pm 28.10 \mathrm{~h}$, with a water withdrawal rate of $0.20 \%$ (w.b.) per hour. Drying on concrete terrace was 2.35 times slower than that using dehydrated air.

Resende et al. (2011) dried coffee in a hybrid terrace drying system at moisture contents ranging from $50 \%$ to $9.5 \%$ (w.b.) and found that the drying time of concrete terraces (168 hours) was 3.1 times higher than that in a mechanical drying system. These authors also observed a moisture withdrawal rate of $0.20 \%$ (w.b.) per hour in concrete terrace and of $0.56 \%$ (w.b.) per hour in the hybrid system.
When analyzing coffee drying in a hybrid terrace system, Donzeles et al. (2008) found a moisture withdrawal rate of $0.81 \%$ (w.b.) per hour, which was 6.7 times lower than that of a concrete terrace. Reinato et al., (2002) investigated energy consumption during coffee drying in rotary dryers and showed that the use of firewood provided a water removal rate of $0.55 \%$ (w.b.) per hour, while the use of liquefied petroleum gas (LPG) provided a rate of $0.77 \%$ (w.b.) per hour; however, coffee beverage quality was not analyzed in this study.

Alves et al. (2017) studied the effect of drying time and rate on coffee physiological traits and concluded that increasing rates affected sensory quality only of pulped coffee, not interfering with those with pulp.

Coelho et al. (2015) evaluated physiological and biochemical changes in coffee seeds subjected to a fastdrying by means of silica gel and to a slow drying with saturated salt solutions; they verified that drying speed has a significant effect on the physiological quality of coffee seeds.

Coffee grain quality after drying is evaluated by discounting points for the number of defective grains found (Santos et al., 2013). Therefore, a poorly conducted drying processes contribute to the devaluation of coffee bag prices. In this sense, we observed that drying rate and non-use of terraces proved to be advantages, improving the final quality of grains.

\section{Variance analysis of drying quality factors}

A significant difference was found between the quality of coffee dried in the evaluated equipment and on concrete terraces at a level of $5 \%$ of significance (Table 2). 
TABLE 2 ANOVA of drying quality factors.

\begin{tabular}{|c|c|c|c|c|c|}
\hline Variation source & & SS & DF & MS & $\mathrm{F}$ \\
\hline \multirow{3}{*}{ Hand-sorting (\%) } & Regression & 270 & 3 & 90 & 83.08 \\
\hline & Residue & 8.67 & 8 & 1.08 & \\
\hline & Total & 278.67 & 11 & & \\
\hline \multirow{3}{*}{ Number of defective grains } & Regression & 7.062 .25 & 3 & 2.35408 & 5.44 \\
\hline & Residue & 3.464 .00 & 8 & 433 & \\
\hline & Total & 10.526 .25 & 11 & & \\
\hline \multirow{3}{*}{ SCAA scoring } & Regression & 71.27 & 4 & 17.82 & 4.16 \\
\hline & Residue & 42.79 & 10 & 4.28 & \\
\hline & Total & 114.06 & 4 & & \\
\hline
\end{tabular}

The results of Fisher-Snedecor F-test for the analyzed factors were over to the critical value (4.06), that is, the samples collected in this experiment presented an adequate variance at a 5\% significance level. The FisherSnedecor value and p-value were 83.08 and $2.310^{-6}$ for the percentage of tasting material, 5.44 and 0.025 for the number of defective grains, 88.16 and $1.810^{-6}$ for the percentage of material retained in \#13 sieve (and larger), and 4.16 and 0.03 for cup test score (SCAA).

Coffee drying in DUs had an average time of $83.33 \pm 6.90 \mathrm{~h}$, with a moisture withdrawal rate of $0.48 \%$ (w.b.) per hour, while the drying in concrete terrace lasted on average $196.02 \pm 28.10 \mathrm{~h}$, with a humidity withdrawal rate of $0.20 \%$ (w.b.) per hour. Thus, the drying on concrete terrace was 2.35 times slower than using dehydrated air. Resende et al. (2011) dried coffee grains using a hybrid terrace system (from 50 to $9.5 \%$ moisture level) and concluded that the drying time in a concrete yard $(168 \mathrm{~h})$ was 3.1 times longer than that in a mechanical drying apparatus.
Donzeles et al. (2008) analyzed the drying of coffee in a hybrid terrace system and perceived a moisture removal rate of $0.81 \%$ (w.b.) per hour, which was 6.7 times shorter than the drying in a concrete yard. Reinato et al. (2002) investigated energy consumption of rotary dryers in coffee drying and noted that the use of firewood provided a moisture extraction rate of $0.55 \%$ (w.b.) per hour, while liquid petroleum gas (LPG) had a rate of $0.77 \%$; however, these authors did not analyze beverage quality.

Given the above, our findings show that the moisture removal rate in dryers with dehydrated air was compatible with those of the other technologies in use, and was also superior to that of concrete terraces. Therefore, these electric dryers with dehydrated air could be used in place of terrace drying.

\section{Hand-sorting and bottom sieve \#13 percentages}

Table 3 shows the means and standard deviations found for samples dried in the DUs and on the terrace.

TABLE 3. Sieving and bottom sieve \#13 percentages of coffee grain samples dried in the DUs and on the concrete terrace.

\begin{tabular}{ccccc}
\hline & DU-A & DU-B & DU-C & DU-D \\
\hline A-1 & 16 & 7 & 19 & 16 \\
A-2 & 16 & 7 & 19 & 19 \\
A-3 & 15 & 6 & 18 & 18 \\
$\bar{y} \pm \mathrm{s}$ & $15.67^{b *} \pm 0.88$ & $6.67^{a *} \pm 1.16$ & $18.67^{\text {b* }} \pm 0.26$ & $17.67^{\text {b* } \pm 1.25}$ \\
\hline C-1 & 32 & 35 & 40 & 29 \\
C-2 & 38 & 42 & 46 & 29 \\
C-3 & 38 & 42 & 46 & 30 \\
$\bar{y} \pm \mathrm{s}$ & $36.00 \pm 3.46$ & $39.67 \pm 4.04$ & $44.00 \pm 3.46$ & $29.33 \pm 0.58$ \\
\hline $\bar{y} \pm \mathrm{s}$ & & & $37.25 \pm 6.24$ & \\
\hline
\end{tabular}

Notes: DU-[ ]: drying unit; A-[ ]: sample of coffee dried in a drying unit; C-[ ]: control sample of coffee dried on the terrace of an agricultural unit (farm); Means followed by the same letter or ns in the row do not differ from each other at $5 \%$ significance level by the Tukey's test. Means followed by * are statistically different from the control treatment at $5 \%$ significance level by the Dunnett's test. 
The percentages of impurities and wastes in the \#13 sieve were lower $(14.70 \pm 4.96 \%)$ in samples of coffee dried using dehydrated air if compared to those of grounddried coffee $(37.57 \pm 6.24 \%)$. Drying in terraces had $255.6 \%$ more impurities, and grains were not retained in \#13 sieve. DU-B had the best performance in terms of impurities and wastes in the \#13 sieve. This factor may have occurred due to the mixture of varieties Novo Mundo and Catuaí in the drying lots of this DU. The means of each DU showed statistical differences comparing the use of dehydrated air and terrace drying. The relationships between drying in DU and on terraces were 0.44 for DUA, 0.17 for DU-B, 0.42 for DU-C, and 0.60 for DU -D.

Ferreira et al. (2013) evaluated the performance of different varieties in the state of Minas Gerais and reported that the variety Catuaí presented a larger grain mass retained in sieve \#16 (and above) when compared to the variety Novo Mundo, demonstrating, and hence a lower percentage of tiny grains.

\section{Number of defective grains}

Table 4 shows the means and standard deviations of defective grains found in samples of coffee dried in the DUs and on the terrace.

TABLE 4 Means and standard deviation of the number of defective grains sampled in DUs and terraces.

\begin{tabular}{ccccc}
\hline & DU-A & DU-B & DU-C & DU-D \\
\hline A-1 & 97 & 36 & 96 & 96 \\
A-2 & 97 & 35 & 129 & 121 \\
A-3 & 95 & 95 & 129 & 120 \\
$\bar{y} \pm \mathrm{s}$ & $96.33^{\mathrm{ab} * \pm 14.53}$ & $56.33^{\mathrm{a} *} \pm 19.24$ & $118.00^{\mathrm{b} *} \pm 34.25$ & $112.33^{\mathrm{b} * \pm 0.39}$ \\
\hline $\mathrm{C}-1$ & 346 & 347 & 347 & 360 \\
C-2 & 246 & 380 & 400 & 360 \\
$\mathrm{C}-3$ & 246 & 380 & 400 & 346 \\
$\bar{y} \pm \mathrm{s}$ & $279.33 \pm 57.74$ & $279.33 \pm 57.74$ & $279.33 \pm 57.74$ & $279.33 \pm 57.74$ \\
\hline $\bar{y} \pm \mathrm{s}$ & & & $346.5+50.93$ & \\
\hline
\end{tabular}

Notes: DU-[ ]: drying unit; A-[ ]: sample of coffee dried in a drying unit; C-[ ]: control sample of coffee dried on the terrace of an agricultural unit (farm); Means followed by the same letter or ns in the row do not differ from each other at $5 \%$ significance level by the Tukey's test. Means followed by * are statistically different from the control treatment at $5 \%$ significance level by the Dunnett's test.

The number of defective grains was lower in the samples of coffee dried in the ATU'DU $(95.72 \pm 31.02)$, representing $27.6 \%$ of the defects found in samples of coffee dried on concrete terraces (346.91 \pm 50.83). Regarding the defect count between the DU, there was a significant difference, between drying unit B (fewer defects) and units $\mathrm{C}$ and $\mathrm{D}$.

According to the means of defective grains in
TABLE 4, no difference was found in the quality of beverage among the DU samples. These findings indicate that mechanical drying in the DU with dehydrated air provided fewer defects in the coffee lots.

\section{Quality score (SCAA)}

Table 5 presents the means and standard deviations of quality scores for the collected samples.

TABLE 5. Means and standard deviations of SCAA cupping score for coffee samples dried in DUs and on terraces.

\begin{tabular}{|c|c|c|c|c|}
\hline & DU-A & DU-B & DU-C & DU-D \\
\hline A-1 & 84 & 80 & 80 & 82 \\
\hline A-2 & 84 & 80 & 85 & 80 \\
\hline A-3 & 82 & 80 & 85 & 82 \\
\hline $\bar{y} \pm s$ & $83.33^{\mathrm{ns}^{*}} \pm 2.14$ & $80.00^{\mathrm{ns}^{*}} \pm 0.33$ & $83.33^{\mathrm{ns}^{*}} \pm 2.7$ & $81.33^{\mathrm{ns}^{*}} \pm 1.07$ \\
\hline $\mathrm{C}-1$ & 79 & 78 & 78 & 77 \\
\hline $\mathrm{C}-2$ & 78 & 78 & 77 & 76 \\
\hline $\mathrm{C}-3$ & 79 & 76 & 78 & 80 \\
\hline $\bar{y} \pm s$ & $78.67 \pm 0.58$ & $78.67 \pm 0.58$ & $78.67 \pm 0.58$ & $78.67 \pm 0.58$ \\
\hline$\overline{\mathrm{y}} \pm \mathrm{s}$ & & & & \\
\hline
\end{tabular}

Notes: DU-[ ]: drying unit; A-[ ]: sample of coffee dried in a drying unit; C-[ ]: control sample of coffee dried on the terrace of an agricultural unit (farm); Means followed by the same letter or ns in the row do not differ from each other at $5 \%$ significance level by the Tukey's test. Means followed by * are statistically different from the control treatment at $5 \%$ significance level by the Dunnett's test. 
According to TABLE 5, the SCAA cupping score for coffee dried in the DUs with dehydrated air reached a mean value of $82.00 \pm 2.07$, thus being classified as soft drink. Ten out of the twelve samples evaluated here were classified as soft drink (SCAA scores between 80 and 84), and the other two coffee-producing as a strictly soft drink (SCAA score above 85).

Coffee beans dried on concrete terraces had a mean SCAA score of $77.83 \pm 4.77$. Five samples were classified as soft drink, six samples as only soft, one as hard, and one scored less than 71 .

The averages in Table 5 show that the poor-quality scores of coffee samples dried on concrete terraces can be attributed to the need for more frequent heap turning. Peske et al., (2012) pointed out a strong association of unfavorable climatic factors with time delay in drying, which impaired coffee quality. For Martinez et al. (2013), the drying on terraces can boost coffee fermentation, decreasing its quality, as fermentation increases grain acidity.

\section{Sale price of coffee bag}

TABLE 6 displays the ANOVA of the sale prices of a $60-\mathrm{kg}$ coffee bag.

The Fisher-Snedecor $\mathrm{F}$ value was 6.36 (critical $\mathrm{F}=$ 3.48 ) and the p-value was $8.210^{-3}$. Based on these values, we observed a statistical difference in prices for coffee dried using dehydrated air if compared to that for grains dried on concrete terraces.

TABLE 6. Analysis of variance (ANOVA) of the sale price of a coffee bag.

\begin{tabular}{ccccc}
\hline & SS & DF & MS & F \\
\hline Regression & 6.143 .48 & 4 & 1.535 .87 & 6.36 \\
Residue & 2.413 .46 & 10 & 241.35 & \\
Total & 8.556 .94 & 14 & & \\
\hline
\end{tabular}

TABLE 7 presents the means and standard deviations of sale prices for coffee dried in DUs and on terraces.

TABLE 7 Means and standard deviations of the selling price of a coffee bag $(60 \mathrm{~kg})$ for samples dried in DUs and on terraces.

\begin{tabular}{ccccc}
\hline & DU-A & DU-B & DU-C & DU-D \\
\hline A-1 & 480.19 & 460.55 & 437.16 & 440.11 \\
A-2 & 455.91 & 462.34 & 490.72 & 454.15 \\
A-3 & 454.27 & 462.66 & 448 & 460.86 \\
$\bar{y} \pm \mathrm{s}$ & $463.46^{\text {ns* }^{*}} \pm 14.51$ & $461.85^{\text {ns* }^{*}} \pm 1.14$ & $458.63^{\text {ns* }^{*}} \pm 28.32$ & $451.71^{\text {ns* }^{*}} \pm 10.59$ \\
\hline C-1 & 418.3 & 405.28 & 412.15 & 410.88 \\
C-2 & 400.19 & 360.95 & 390.42 & 427.22 \\
C-3 & 418.45 & 435.65 & 402.32 & 430.15 \\
$\bar{y} \pm s$ & $412.31 \pm 10.50$ & $412.31 \pm 10.50$ & $412.31 \pm 10.50$ & $412.31 \pm 10.50$ \\
\hline $\bar{y} \pm s$ & \multicolumn{4}{c}{$409.33 \pm 20.15$} \\
\hline
\end{tabular}

Notes: DU-[ ]: drying unit; A-[ ]: sample of coffee dried in a drying unit; C-[ ]: control sample of coffee dried on the terrace of an agricultural unit (farm); Means followed by the same letter or ns in the row do not differ from each other at 5\% significance level by the Tukey's test. Means followed by * are statistically different from the control treatment at $5 \%$ significance level by the Dunnett's test.

Trading prices (reais per $60-\mathrm{kg}$ bag) of the samples studied here, dried in DUs and on terraces, presented a homogeneous residual distribution, and Shapiro-Wilk W factor equals to 0.96 , i.e., a low data dispersion. The prices attributed to coffee samples dried in DUs showed no differences among the evaluated farms.

As shown in TABLE 7, there was a significant difference (Dunnett's test at 5\% significance level) between both drying techniques. Coffee beans dried in DUs showed a mean price per bag of $\mathrm{R} \$ 458.91 \pm 15.06$, which was significantly higher than that of lots dried on terraces $(\mathrm{R} \$ 409.33 \pm 20.15)$, representing an appreciation of $12.11 \%$ for coffee dried in DUs.

This price rise of $\mathrm{R} \$ 50.58$ (average) in $60-\mathrm{kg}$ coffee bags would raise the gains in lots of $75 \mathrm{~m}^{3}$ by $\mathrm{R} \$$ $7,903.13$, considering an average production yield of $500 \mathrm{~L}$ cherry coffee per $60 \mathrm{~kg}$ bag of coffee benefited (Fundação PROCAFÉ, 2016).

Among coffee drying techniques, the most wellestablished is drying on concrete terraces. But, if mishandled, it devalues the product due to depletion in grain quality (Coradi et al., 2008).

The drying in DUs promoted a reduced number of broken coffee grains and lower content of impurities in drying lots. These factors appear to be advantageous for specialty coffees, which require greater management control. This way, small farmers would be able to use DU since they have a maximum capacity of $75 \mathrm{~m}^{3}$. In this sense, Frederico \& Barone (2015) argued that specialty coffees have been one of the main market alternatives for small coffee growers; these authors analyzed market insertion of small producers and debated globalization and standardization of specialty coffee production.

Some authors such as Krzyzanowski et al., (2006a); Krzyzanowski et al., (2006b); Levien et al., (2008); and Avelar et al., (2011), have already tested the heat pipe technology (HPT) and proved its efficiency in drying grains. In coffee, this drying method also showed results that corroborate our findings on the maintenance of grain quality. 


\section{CONCLUSIONS}

The drying units (DUs) could dry coffee grains with $60 \%$ initial moisture content (w.b.) directly. This use of an ATU equipment coupled to $\mathrm{SBJ}^{\circledR}$ dryers produced coffee grains with higher quality than those dried on concrete terraces.

Coffee samples dried in the DUs had a greater amount of beans retained in sieve \#17, higher cupping scores, and reductions hand-sorting and defects.

The mean market value of coffee lots dried in DUs was $12.11 \%$ higher than that of coffee lots dried on concrete terrace.

\section{ACKNOWLEDGMENTS}

To Coolseed Company for the assignment of $\mathrm{SBJ}^{\circledR}$ and $\mathrm{ATU}^{\circledR}$ data, to farmers through the drying data section, to Federal Technological University of Paraná (UTFPR) for freeing time for study, to Western Paraná State University (UNIOESTE) and Graduate Program in Agricultural Engineering (PGEAGRI) for the acceptance of research in the graduate program.

This study was financed in part by the Coordenação de Aperfeiçoamento de Pessoal de Nível Superior - Brasil (CAPES) - Finance Code 001

\section{REFERENCES}

Abrahão AS, Pereira RGFA, Duarte SMS, Lima AR, Alvarenga DJ, Ferreira EB (2010) Compostos bioativos e atividade antioxidante do café (Coffea arabica L.). Ciência e Agrotecnologia 34(2):414-420. DOI:

http://dx.doi.org/10.1590/S1413-70542010000200020

Alves GE, Borém FM, Isquierdo EP, Siqueira V, Cambuy C, Pinto MA, Ferreira AC (2017) Physiological and sensorial quality of Arabica coffee subjected to different temperatures and drying airflows. Acta Scientiarum. Agronomy 39(2):225-233.

https://dx.doi.org/10.4025/actasciagron.v39i2.31065

Aparecido LEO, Rolim GS, Lamparelli RAC, Souza PS \& Santos ER (2016) Agrometeorological models for forecasting coffee yield. Agronomy Journal, Madison, 109:249-258. DOI:

http://dx.doi.org/10.2134/agronj2016.03.0166

Aparecido LEO, Rolim GS, Souza PS (2015) Sensitivity of newly transplanted coffee plants to climatic conditions at altitudes of Minas Gerais, Brazil. Australian Journal of Crop Science 9(2):160-167.

Avelar SAG, Levien AM, Peske ST, Villela FA, Baudet L (2011) Secagem estacionária de sementes de soja com ar desumidificado por resfriamento. Revista Brasileira de Sementes 33(3):454-462. DOI: https://dx.doi.org/10.1590/S0101-31222011000300008

Batista LA, Guimarães RJ, Pereira FJ, Carvalho GR, Castro EM (2010) Anatomia foliar e potencial hídrico na tolerância de cultivares de café ao estresse hídrico. Revista Ciência Agronômica 41(3):475-481.

Brasil (2003) Instrução Normativa n. 8, de 11 de junho de 2003. Aprova o regulamento técnico da identidade e de qualidade para a classificação de café beneficiado grão cru. Brasília, DF.
Coelho SVB, Figueiredo MA de, Clemente A da CS, Coelho LFS, Rosa SDVF da (2015) Alterações fisiológicas e bioquímicas em sementes de café secas em sílica gel e soluções salinas saturadas. Pesquisa Agropecuária Brasileira 50(6):483-491. https://dx.doi.org/10.1590/S0100-204X2015000600007

CONAB (2017) Companhia Nacional de Abastecimento. Acompanhamento da Safra Brasileira: café. Quarto Levantamento - Dezembro/2017. CONAB. v4, n4.

Coradi PC, Borém FM, Oliveira JA (2008) Qualidade do café natural e despolpado após diferentes tipos de secagem e armazenamento. Revista Brasileira de Engenharia Agrícola e Ambiental 12(2):181-188. DOI: http://dx.doi.org/10.1590/S1415-43662008000200011

Donzeles SML, Silva JS, Corrêa PC, Magalhães EA, Silva RN, Melo FAO (2008) Análise do terreiro híbrido trabalhando com apenas ar aquecido na secagem de café (Coffea arabica L.). Revista Brasileira de Armazenamento 10:73-79.

Ferreira AD, Carvalho GR, Rezende JC, Botelho CE, Rezende RM, Carvalho AM (2013) Desempenho agronômico de seleções de café Bourbon Vermelho e Bourbon Amarelo de diferentes origens. Pesquisa agropecuária brasileira 48(4):388-394. DOI: http://dx.doi.org/10.1590/S0100-204X2013000400006

Frederico S, Barone M (2015) Globalização e cafés especiais: a produção do comércio justo da Associação dos Agricultores Familiares do Córrego D’Antas ASSODANTAS, Poços de Caldas (MG). Sociedade \& Natureza 27(3):393-404. https://dx.doi.org/10.1590/1982451320150303

Fundação PROCAFÉ (2016) Quantos litros de café tenho em uma saca de café em coco? Como é essa medição por planta e como calculo o rendimento de litros em relação ao de sacos/ha? Available:

http://www.fundacaoprocafe.com.br/faq/outros-assuntos$\mathrm{t} \% \mathrm{C} 3 \% \mathrm{~A} 9 \mathrm{cnicos} /$ quantos-litros-de-caf $\% \mathrm{C} 3 \% \mathrm{~A} 9$-tenhoem-uma-saca-de-caf $\% \mathrm{C} 3 \% \mathrm{~A} 9$-em-coco-como- $\% \mathrm{C} 3 \% \mathrm{~A} 9$ essa-me. Accessed: Apr 02, 2019.

Krzyzanowski FC, West SH, Franca Neto JB (2006a) Drying peanut seed using air ambient temperature at low relative humidity. Revista brasileira de sementes 28(3):1-5. DOI: http://dx.doi.org/10.1590/S0101-31222006000300001

Krzyzanowski FC, West SH, Franca Neto JB (2006b) Drying soybean seed using air ambient temperature at low relative humidity. Revista brasileira de sementes 28(2):7783. DOI: http://dx.doi.org/10.1590/S010131222006000200010

Levien A, Baudet L, Peske S (2008) Stationary drying of soybean seed using drying air of different relative humidities. Seed Science and Technology 36(1):148-156. DOI: http://dx.doi.org/10.1590/S0101-31222011000300008 
Lingle TR (2011) The coffee cupper's handbook: systematic guide to the sensory evaluation of coffee's flavor. Long Beach, California: Specialty Coffee Association of America, 4 ed. 66p.

Martinez HEP, Poltronieri Y, Farah A, Perrone D (2013) Zinc supplementation, production and quality of coffee beans. Revista Ceres 60(2):293-299. DOI: http://dx.doi.org/10.1590/S0034-737X2013000200020

Palacin JJF, Lacerda Filho AF, Melo EC, Teixeira EC (2009) Secagem combinada de café cereja descascado. Revista Engenharia na Agricultura 17(3):244-258.

Peske ST, Rosenthal MD, Rota GRM (2012) Sementes: fundamentos científicos e tecnológicos. Pelotas, Editora rua Pelotas, 3 ed. 573p.

Reinato CHR, Borém FM, Vilela ER, Carvalho FM, Meireles EP (2002) Consumo de energia e custo de secagem de café cereja em propriedades agrícolas do sul de Minas Gerais. Revista brasileira de engenharia agrícola e ambiental 6(1):112-116. DOI:

http://dx.doi.org/10.1590/S1415-43662002000100020
Resende O, Afonso Junior PC, Correa PC, Siqueira VC (2011) Qualidade do café conilon submetido à secagem em terreiro híbrido e de concreto. Ciência Agrotecnica 35(2):327-335. DOI: http://dx.doi.org/10.1590/S141370542011000200014

Santos FL, Nantes JFD (2014) Coordenação no mercado do café brasileiro: o desserviço da classificação por defeitos. Gestão \& Produção 21(3):586-599. https://dx.doi.org/10.1590/S0104-530X2014000300011

Santos ESM, Deliza R, Freitas DGC, Corrêa FM (2013) Effect of conilon beans on the sensory profile and consumer acceptance of coffee beverages. Semina: Ciências Agrárias 34(5):2297-2306.

http://www.uel.br/revistas/uel/index.php/semagrarias/articl e/view/13803/pdf_28

Zelber-Sagi S, Salomone F, Webb M, Lotan R, Yeshua H, Halpern Z, Shibolet O (2015) Coffee consumption and nonalcoholic fatty liver onset: a prospective study in the general population. Translational Research 165:428-436. DOI: https://doi.org/10.1016/j.trsl.2014.10.008 